\title{
REGISTER ZGRADB V RAČUNALNIŠKO PODPRTIH ODLOČITVENIH MODELIH PROSTORSKE EKONOMIKE
}

\author{
Marija Bogataj in Samo Drobne
}

\section{Izvleček}

UDK $332: 528.065$

Za uspešno aplikacijo teoretičnih rešitev s področja urbane in regionalne ekonomike za reševanje praktičnih problemov $v$ slovenskem prostoru je potrebna ustrezna računalniška podpora, saj zaradi interakcij med dejavnostmi v prostoru in večkriterialnega odločanja na različnih nivojih upravljanja s prostorskimi sistemi parcialne rešitve ne dajo ustreznih rezultatov. V članku podajamo teoretična izhodišča $z a$ dvodimenzionalne probleme, $k i$ so $v$ praksi sicer večdimenzionalni. Pri tem izhajamo predusem iz teoretičnih rešitev Alonsoja. Podajamo matematična izhodišča za izgradnjo skeleta odločitvenih modelov. $V$ članku še posebej opozarjamo na tiste obvezne elemente podatkoune baze $v$ jedru GIS, brez katerih uspešno upravljanje hierarhičnih prostorskih struktur ni mogoče.

\section{Abstract}

UDC $332: 528.065$

\section{BUILDING AND DWELLING REGISTER IN THE COMPUTER SUPPORTED DECISSION MODELS OF SPATIAL ECONOMICS}

The theoretical results, that originate from the theory of the urban economics and from other theories of spatial economics, can be successfully applied on the urban growth control in Slovenia if there is available GIS with Building and Dwelling Register (BDR) embedded in it. BDR will enable us to upgrade the relevant MASS appraisal and to formalise the skeleton for multicriterion, multilevel decision models. In this paper the simple spatial decision results (originated from some basic Alonso's considerations) are discussed, which have to be studied simultaneously in the models of spatial interactions and supported by GIS, where Building and Dwelling Register is playing its role. How to construct this register, which will support the decision models, is briefly discussed.

\section{UVOD}

Med temeljne probleme, ki jih srečamo pri aplikaciji urbane ekonomike in drugih vej prostorske ekonomike $\mathbf{v}$ aktualne prostorske rešitve, sodi problem izgradnje integriranega prostorskega informacijskega sistema. Le-ta je $v$ Sloveniji šele $v$ prvih fazah razvoja, in do sedaj ni nudil povezav za uporabo ustreznih odločitvenih modelov $v$ prostoru. Takšen sistem

Prof. Marija Bogataj, Samo Drobne, dipl. ing FAGG, Jamova 2, 61000 Ljubljana 
bi moral prostorskim ekonomistom in drugim planerjem $\mathrm{v}$ prostoru, kakor tudi upravljalcem operativnih funkcij $\mathrm{v}$ prostoru, nuditi informacijsko podporo na vseh področjih urbanske in regionalne ekonomike. Naštejmo nekaj takih področij dela:

- analiza lokacije posameznih dejavnosti $\mathrm{v}$ naseljih in usmerjanje željene alokacije $\mathrm{v}$ prostoru, tudi $\mathrm{z}$ ustrezno fiskalno-tržno politiko;

- reševanje problemov hierarhije naselij $\mathrm{v}$ prostoru, vključno $\mathrm{z}$ analizo njihove gospodarske rasti in alokacije kapitala $\mathrm{v}$ prostoru;

- reševanje problema velikosti naselij $\mathrm{z}$ vidika internih in eksternih ekonomskih učinkov in še predvsem $z$ vidika internalizacije eksternih stroškov, predvsem tistih, ki so povezani $z$ vprašanjem polucije;

- dinamična analiza vplivov urbanih sprememb na spremembe $\mathrm{v}$ narodnem dohodku, $\mathrm{z}$ vidika demografskih sprememb, sprememb $\mathrm{v}$ proizvodnih tehnologijah in transportnih zmožnostih ...;

- reševanje problemov zemljiške politike $\mathrm{v}$ naseljih, analize trga zemljišč $\mathrm{v}$ prostoru in vprašanje mestne rente;

- reševanje problema lokalnih uprav in financiranje infrastrukturnega gospodarstva;

- analiza trga delovne sile v naseljih (še predvsem v večjih mestih);

- reševanje problema urbanega transporta, še predvsem $v$ interakciji $z$ rabo zemljišč v razvoju naselij;

- analiza vplivov prostorsko planerskih omejitev in vplivov davčne politike na urbani razvoj in njegovo ekonomsko uspešnost .... .

$\mathrm{V}$ zadnjem času se tudi $\mathrm{v}$ svetu posveča vse več pozornosti cenilstvu nepremičnin $\mathrm{v}$ mestih in drugih naseljih. To področje intenzivneje prehaja iz ocenjevanja vloženega kapitala $\mathrm{v}$ nepremičnino, $\mathrm{v}$ analizo lokacijskih prednosti nepremičnin $\mathrm{v}$ prostoru, ki se izraža $\mathrm{v}$ višjem bruto dohodku oziroma nižjih stroških uporabnikov mestnih zemljišč $\mathrm{v}$ dejavnosti sami, pri prenosu lastništva v višji kupnini, pri prenosu pravice rabe pa v višji renti. Takšne cenitve ne služijo samo zajemanju rente $v$ dejavnosti oziroma davčni politiki ob prenosu lastništva, ampak so pomemben temelj krojitvi hipotekarskih odločitev oziroma cenitev rizika in določitev višine posojil pri podpori investicijski politiki $v$ prostoru. Zadnje je tudi pomemben vzvod nacionalnega gospodarskega razvoja. $\mathrm{V}$ tem se loči lokacijski pristop v cenilstvu, ki upošteva tudi pričakovano gospodarsko rast ali nazadovanje na določenem teritoriju, od cenilstva vloženega kapitala, ki je zanimivo tako za zavarovalniško politiko kot tudi za analizo uspešnosti vlaganj $\mathrm{v}$ prostor. Tovrstno cenilstvo bi moralo postati ena obveznih faz urbanega oziroma širšega prostorskega managementa.

Za reševanje teh problemov je potrebno zgraditi ustrezno informacijsko bazo $\mathrm{v}$ jedru GIS, za podporo odločitvam pa tudi ustrezne odločitvene modele.

Temu cilju smo prilagodili tudi podatkovno zasnovo $\mathrm{v}$ konkretni aplikaciji Registra zgradib v ORACLE RDBMS, ki jo podrobneje predstavljamo v 
nadaljevanju tega prispevka. Na tako zasnovani podatkovni strukturi bomo zgradili nekatere temeljne cenilske funkcije kakor tudi funkcije spremljanja investicij $v$ nepremičnine. Funkcijo podatkovne baze upravljalcev nepremičnin in njeno vpetost $v$ zemljiško politiko $v$ prostoru prikazuje slika 1.

Slika 1: Funkcija podatkoune baze upravljalca nepremičnin in njena upetost $v$ zemljiško politiko $v$ prostoru.

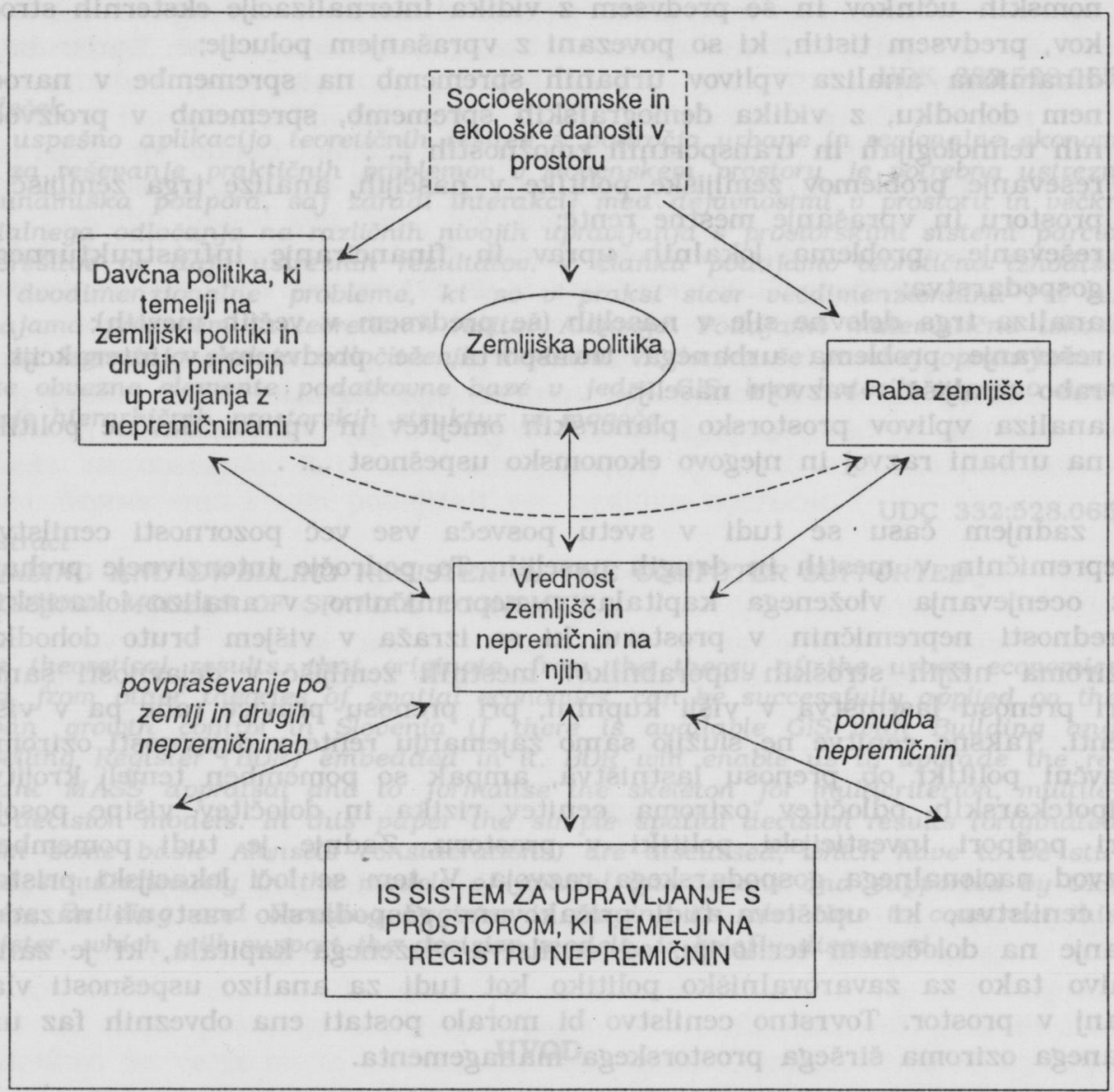

\section{POSLEDICE ODLOČITEV V MONOCENTRIČNIH URBANIH SISTEMIH}

Različne lokacije $\mathrm{v}$ naseljih so za različne dejavnosti različno pridobitno ugodne oziroma nudijo različno kvaliteto bivanja posameznemu uporabniku. Posamezni uporabnik bo za svoje bivanje izbral lokacijo, kjer se doti- 
kata njegova ploskev konstantnih ugodnosti in ploskev možnih izbir (glej tudi Alonso, 1964), kar ponazarja slika 2.

Slika 2: Dotikališče ploskve konstantne ugodnosti $v$ optimalni točki (tako posameznik $v$ množici razpoložljivih parcel najde optimalno lego za svoje bivališče).

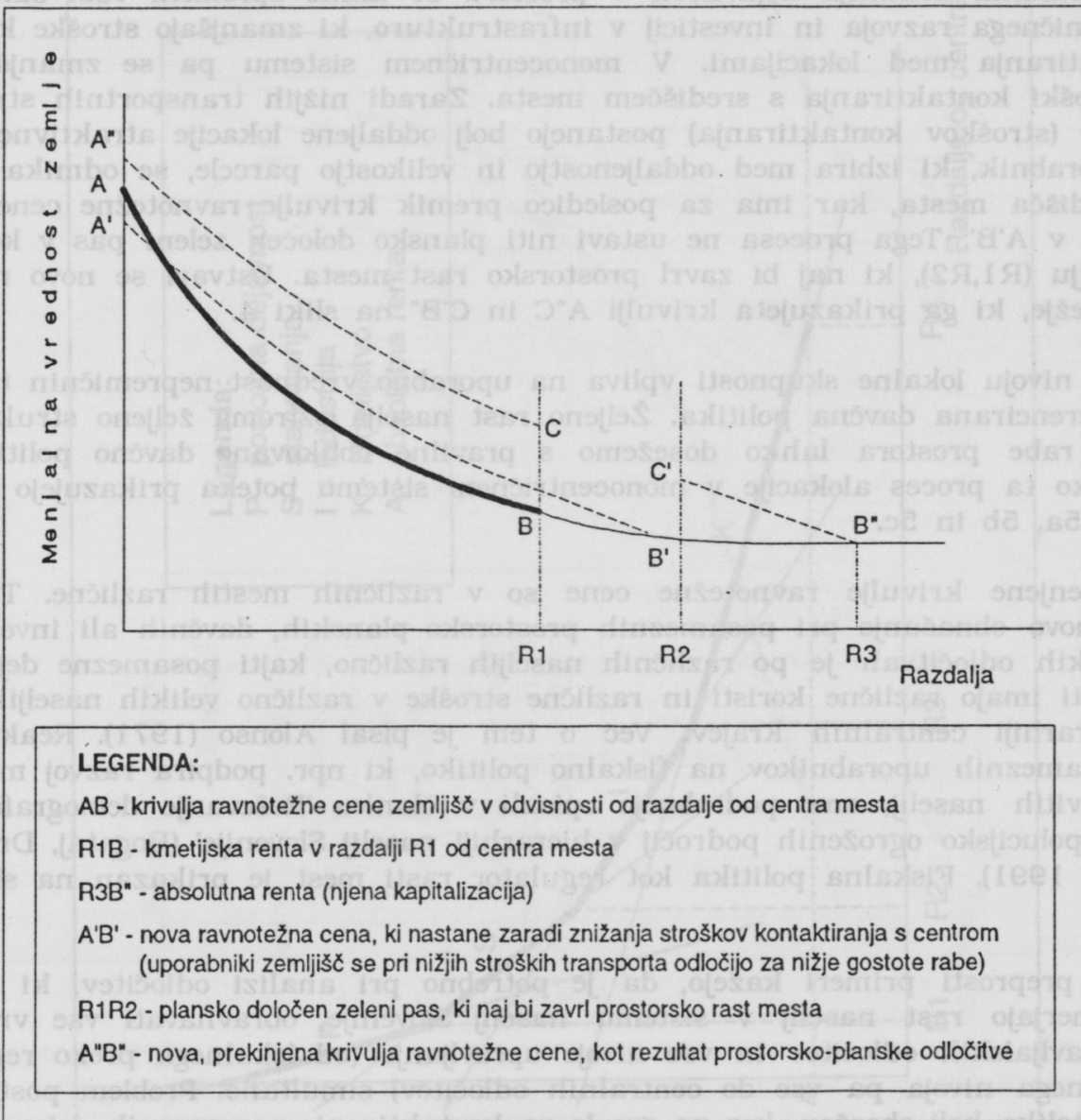

Ti ploskvi se s časom spreminjata. Nanju vplivajo predvsem stopnja ekonomskega razvoja $\mathrm{v}$ prostoru in višina sredstev, $\mathrm{s}$ katerimi razpolaga posameznik, diferencirana davčna politika, investicije $\mathrm{v}$ prostor in tehnični razvoj, ki olajša kontakte med lokacijami, negativni vplivi onesnaženosti prostora ter prostorsko-planske omejitve. Oglejmo si nekaj takih vplivov v monocentričnem sistemu. 
Ob pogojih nemotenega razvoja monocentričnega sistema, ko v razvoj ne posegajo niti prostorsko-planske omejitve niti fiskalna politika in se nivo tehničnega razvoja ne spreminja, se oblikuje krivulja ravnotežne cene zemljišč kot krivulja maksimalnih uporabnih vrednosti različnih uporabnikov zemljišč, kar je prikazano na sliki 3a (glej tudi Alonso, 1964). S prostorsko planskimi omejitvami se optimalna alokacija poruši, kot je to pokazano na sliki $3 b$.

Optimalna alokacija dejavnosti $\mathrm{v}$ prostoru se lahko spremeni tudi zaradi tehničnega razvoja in investicij $\mathrm{v}$ infrastrukturo, ki zmanjšajo stroške kontaktiranja med lokacijami. V monocentričnem sistemu pa se zmanjšajo stroški kontaktiranja s središčem mesta. Zaradi nižjih transportnih stroškov (stroškov kontaktiranja) postanejo bolj oddaljene lokacije atraktivnejše, uporabnik, ki izbira med oddaljenostjo in velikostjo parcele, se odmika od središča mesta, kar ima za posledico premik krivulje ravnotežne cene iz AB v A'B'. Tega procesa ne ustavi niti plansko določen zeleni pas $v$ kolobarju (R1,R2), ki naj bi zavrl prostorsko rast mesta. Ustvari se novo rav-

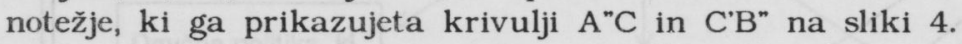

$\mathrm{Na}$ nivoju lokalne skupnosti vpliva na uporabno vrednost nepremičnin tudi diferencirana davčna politika. Željeno rast naselja oziroma željeno strukturo rabe prostora lahko dosežemo s pravilno oblikovano davčno politiko. Kako ta proces alokacije $\mathrm{v}$ monocentričnem sistemu poteka prikazujejo slike $5 a, 5 b$ in $5 c$.

Omenjene krivulje ravnotežne cene so $\mathrm{v}$ različnih mestih različne. Tudi njihovo obnašanje pri posameznih prostorsko-planskih, davčnih ali investicijskih odločitvah je po različnih naseljih različno, kajti posamezne dejavnosti imajo različne koristi in različne stroške $\mathrm{v}$ različno velikih naseljih $\mathrm{v}$ hierarhiji centralnih krajev. Več o tem je pisal Alonso (1971). Reakcijo posameznih uporabnikov na fiskalno politiko, ki npr. podpira razvoj manj razvitih naselij, smo podrobneje opisali $v$ članku 'Reševanje demografsko in polucijsko ogroženih področij v hierarhiji naselij Slovenije' (Bogataj, Drobne, 1991). Fiskalna politika kot regulator rasti mest je prikazan na sliki 6.

Ti preprosti primeri kažejo, da je potrebno pri analizi odločitev, ki naj usmerjajo rast naselij $v$ sistemu naselij Slovenije, obravnavati vse vrste upravljalskih odločitev in vse nivoje upravljanja (od lokalnega preko regionalnega nivoja pa vse do centralnih odločitev) simultano. Problem postaja še toliko bolj obsežen, ker ne gre le za kontaktiranje posameznih dejavnosti s centrom $v$ monocentričnih naseljih, ampak za interakcije med posameznimi dejavnostmi na različnih lokacijah $\mathrm{v}$ naselju in za relacije $\mathrm{v}$ hierarhiji naselij hkrati. Zato je potrebno slediti vsem lokacijam in tokovom med njimi. Le-to nam omogočajo relevantne informacije, ki slonijo na razširjeni podatkovni bazi registra zgradb in podatkovnih bazah infrastrukturnih mrež, ki omogočajo kontakte med lokacijami. Te bodo podprte s podatkovnimi bazami v GIS; pri tem pa je nosilec pretežnih podatkov o lokacijah in dejavnostih na njih Register zgradb. 
Slika 3a: Raunotežna cena zemljišča kot krivulja maksimalnih uporabnih vrednosti zemljišč.

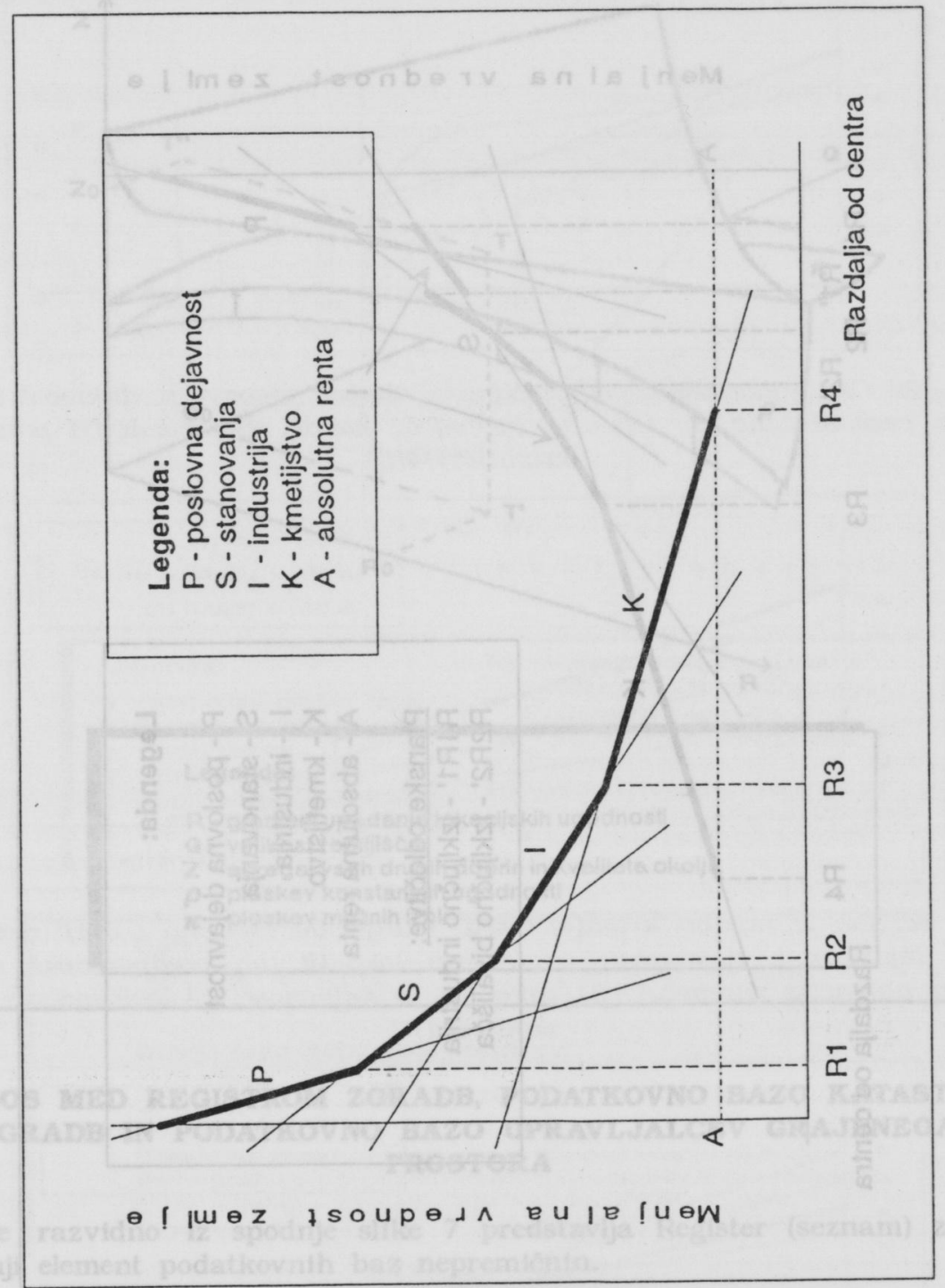


Slika 3b: Vpliv planske odločitve na menjalno vrednost zemlje ob nespremenjenem skupnem poupraševanju.

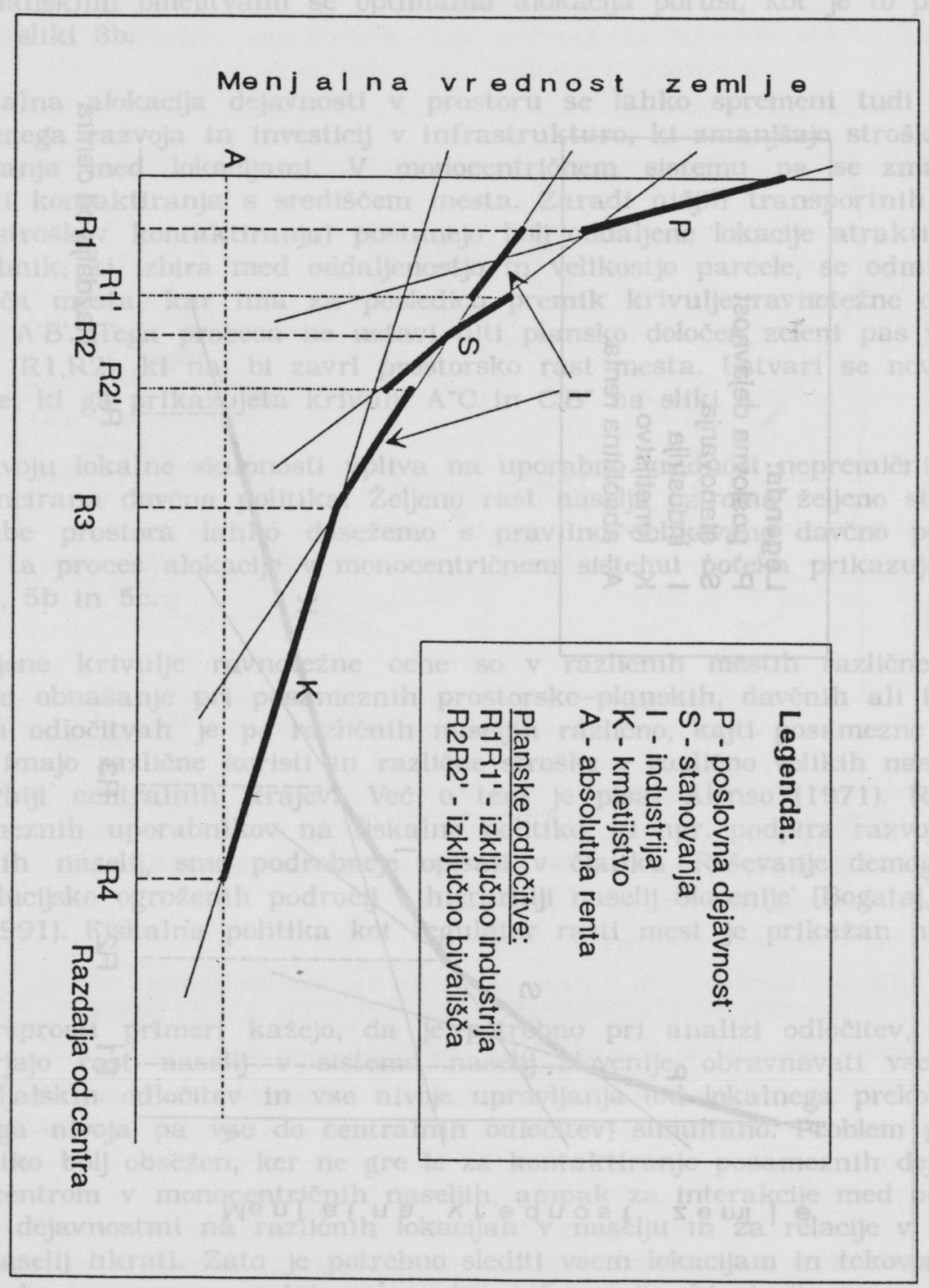


Slika 4: Vpliv planske opredelitve zelenega pasu na menjalno vrednost zemlje ob znižanih stroških transporta.

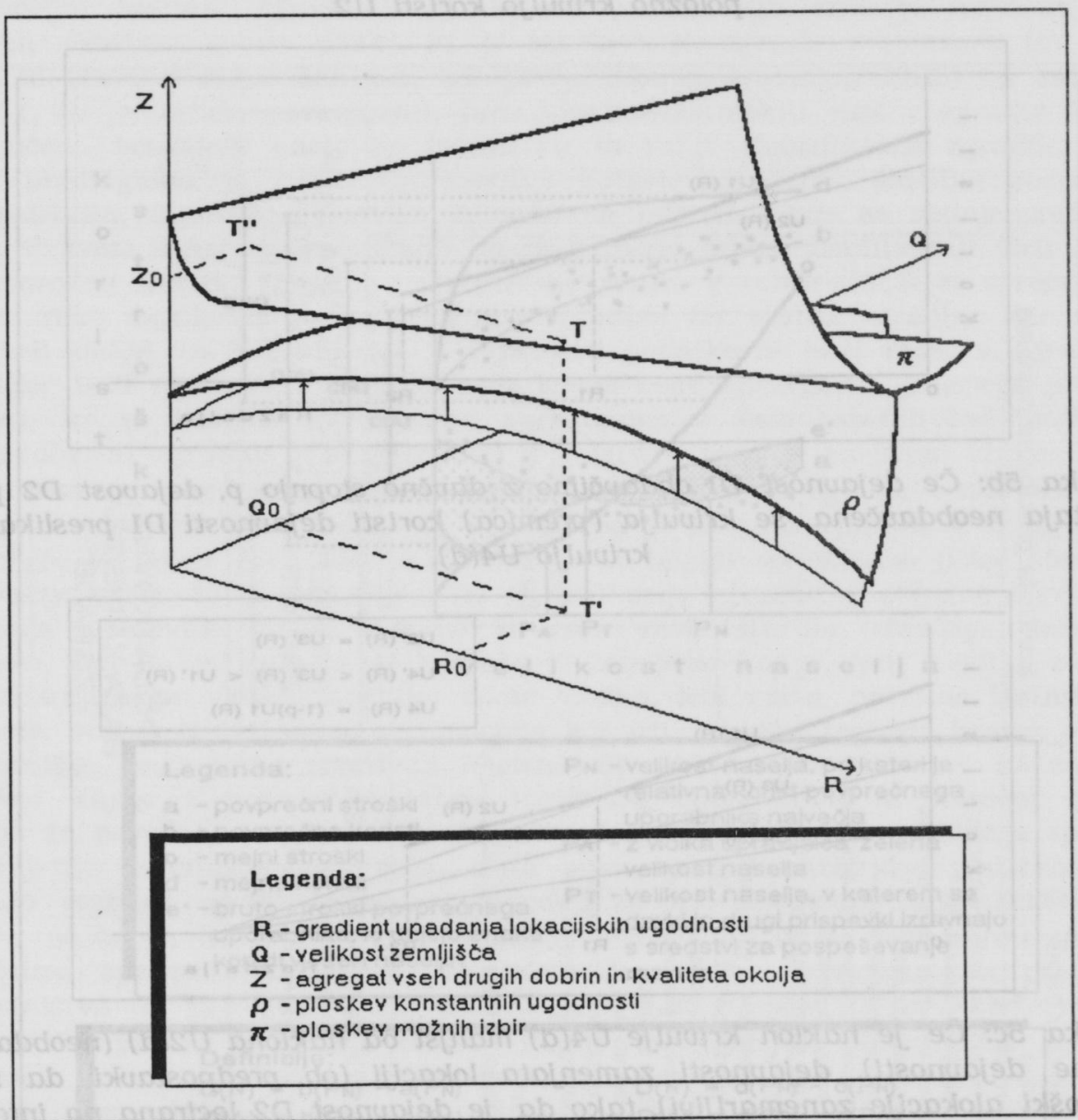

\section{ODNOS MED REGISTROM ZGRADB, PODATKOVNO BAZO KATASTRA ZGRADB IN PODATKOVNO BAZO UPRAVLJALCEV GRAJENEGA PROSTORA}

Kot je razvidno iz spodnje slike 7 predstavlja Register (seznam) zgradb osrednji element podatkovnih baz nepremičnin.

Register zgradb je torej tisti osnovni povezovalni element $\mathrm{v}$ integriranih prostorskih informacijskih sistemih, preko katerega lahko spremljamo vse na grajen prostor vezane pojave. Pri graditvi podatkovnega modela smo 
Slika 5a: Naklon krivulje koristi, ki je za različne dejaunosti različen, določa lokacijo posameznih dejaunosti $v$ prostoru. $\mathrm{Na}$ sliki je dejaunost D1 s krivuljo koristi U1 bliže središču mesta kot dejavnost D2 z bolj položno krivuljo koristi U2.

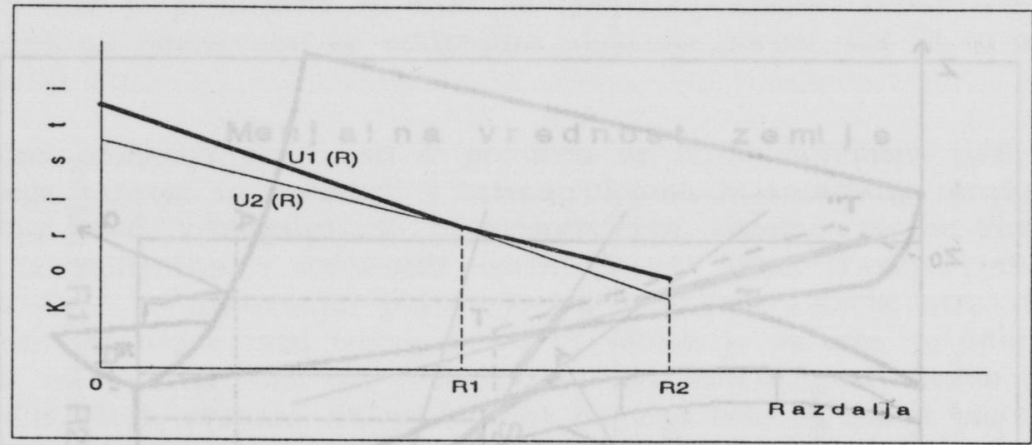

Slika 5b: Če dejavnost D1 obdavčimo z davčno stopnjo $p$, dejavost D2 pa ostaja neobdavčena, se krivulja (premica) koristi dejavnosti D1 preslika $v$ krivuljo $U 4(d)$.

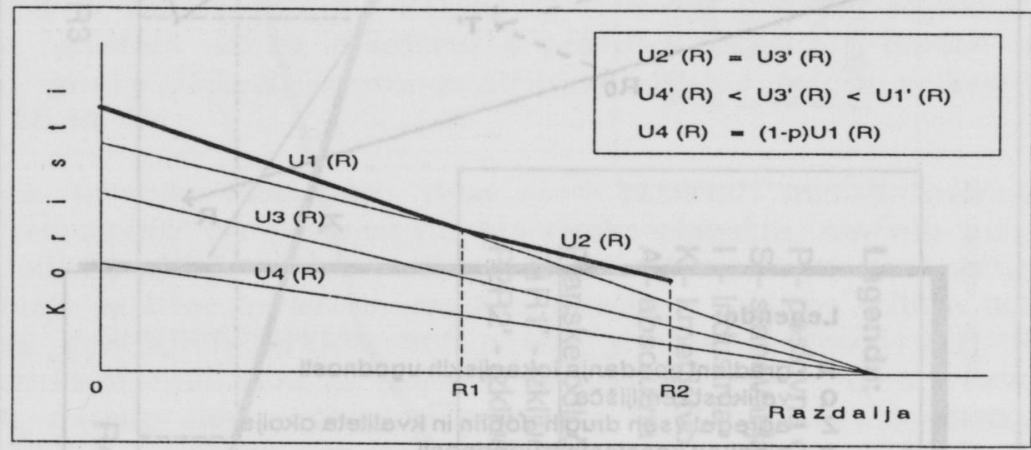

Slika 5c: Če je naklon krivulje U4(d) manjši od naklona U2(d) (neobdavčene dejaunosti), dejaunosti zamenjata lokaciji (ob predpostavki, da so stroški alokacije zanemarljivi), tako da je dejaunost D2 locirana na intervalu $\left(0, d 1^{*}\right)$.

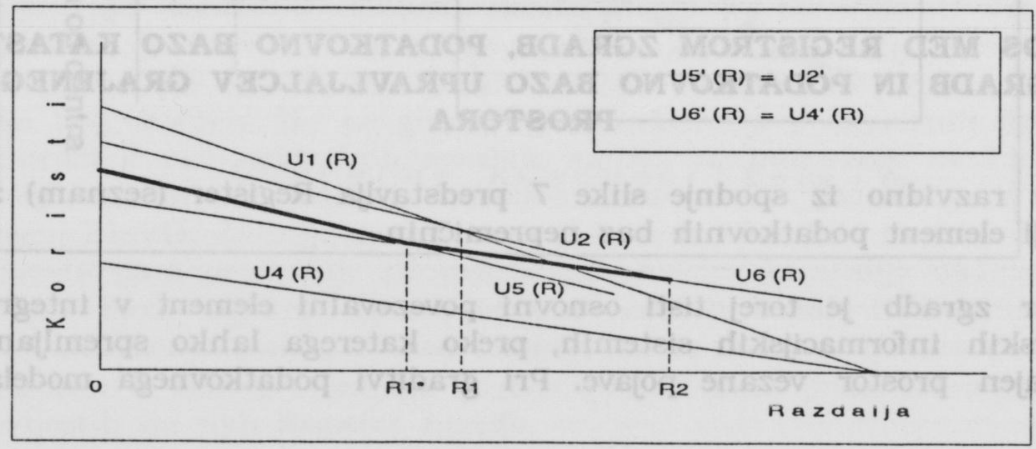


Slika 6: Fiskalna politika kot regulator rasti centralnih krajev.

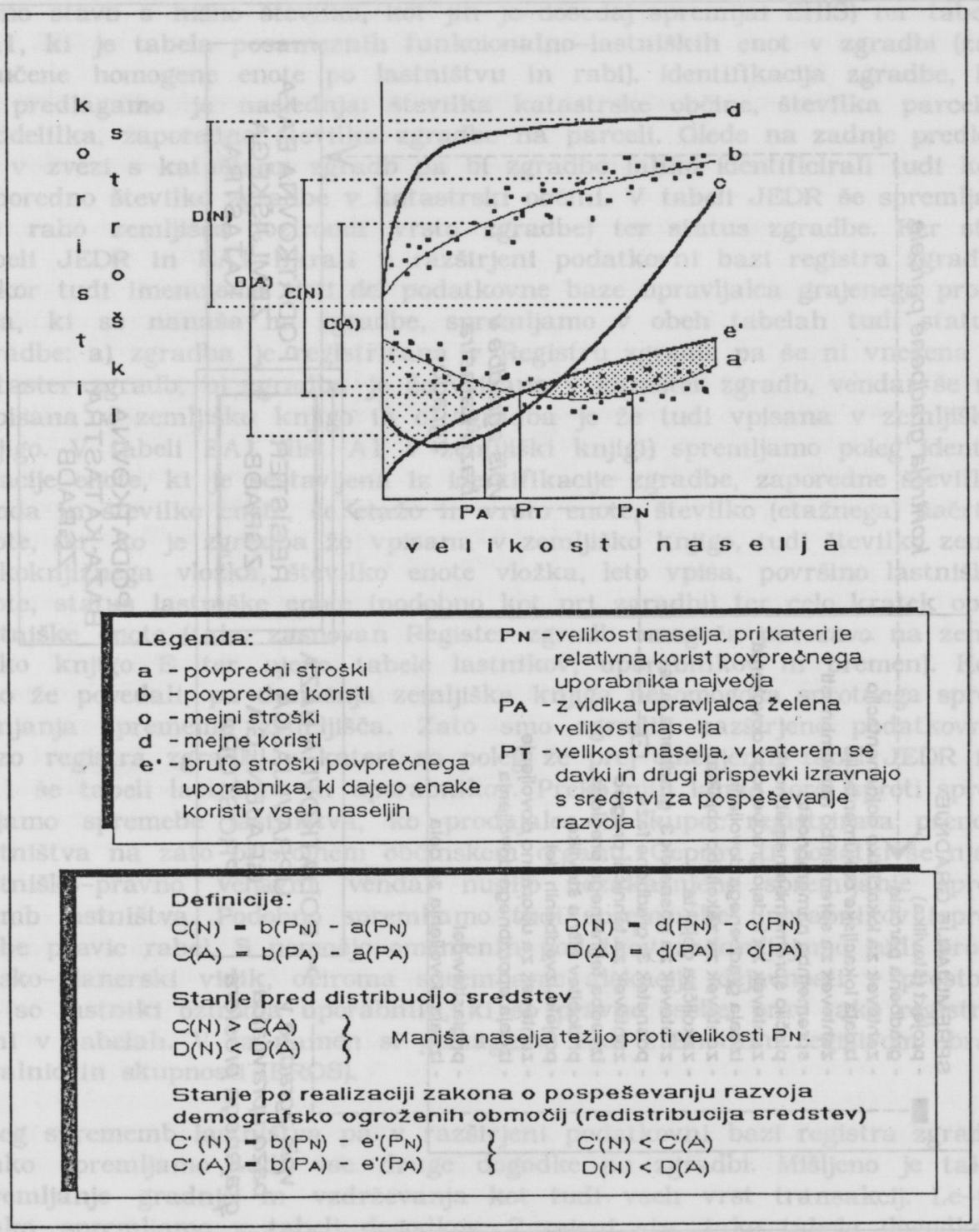


Slika 7: Sovistnost podatkounih baz in Register zgradb.

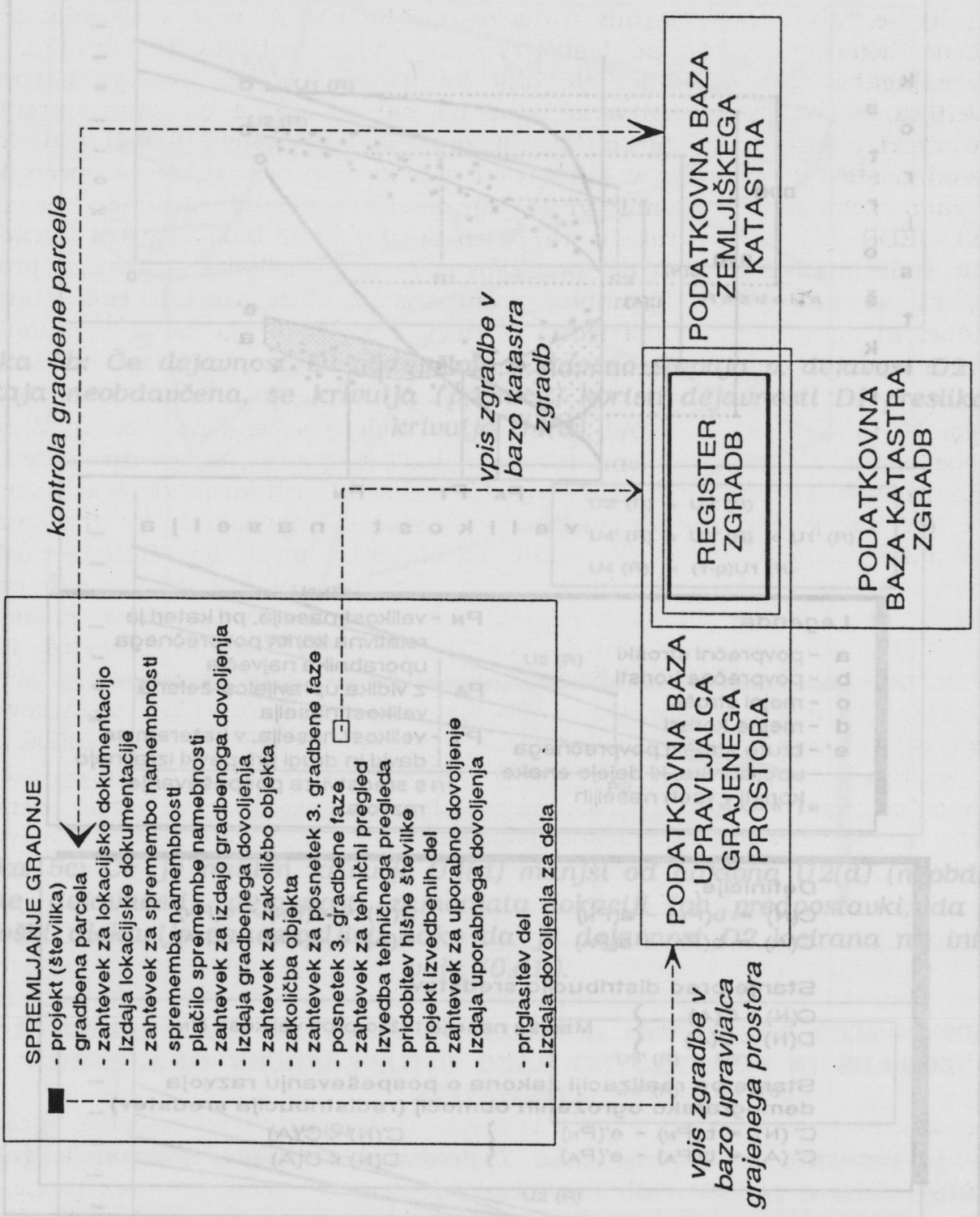


izhajali predvsem iz lastniških, prostorsko-planskih in fiskalnih vidikov odločanja $\mathrm{v}$ prostoru.

Temeljni seznam zgradb in funkcionalno-lastniških enot je vsebovan $v$ dveh tabelah: tabeli JEDR, ki je tabela vseh zgradb v prostoru (in ne samo stavb s hišno številko, kot jih je dosedaj spremljal EHIŠ) ter tabeli EA l, ki je tabela posameznih funkcionalno-lastniških enot $v$ zgradbi (zaključene homogene enote po lastništvu in rabi). Identifikacija zgradbe, ki jo predlagamo je naslednja: številka katastrske občine, številka parcele, poddelilka, zaporedna številka zgradbe na parceli. Glede na zadnje predloge $v$ zvezi s katastrom zgradb pa bi zgradbo lahko identificirali tudi kot zaporedno številko zgradbe $\mathrm{v}$ katastrski občini. V tabeli JEDR še spremljamo rabo zemljišča (oziroma vrsto zgradbe) ter status zgradbe. Ker sta tabeli JEDR in EAl hkrati $v$ razširjeni podatkovni bazi registra zgradb, kakor tudi imenujemo tisti del podatkovne baze upravljalca grajenega prostora, ki se nanaša na zgradbe, spremljamo $v$ obeh tabelah tudi status zgradbe: a) zgradba je registrirana $v$ Registru zgradb, pa še ni vnešena $v$ kataster zgradb, b) zgradba je že vrisana v kataster zgradb, vendar še ni zapisana $\mathrm{v}$ zemljiško knjigo in c) zgradba je že tudi vpisana $v$ zemljiško knjigo. V tabeli EAl (list Al v zemljiški knjigi) spremljamo poleg identifikacije enote, ki je sestavljena iz identifikacije zgradbe, zaporedne številke vhoda in številke enote, še etažo in vrsto enote, številko (etažnega) načrta enote, ter, ko je zgradba že vpisana v zemljiško knjigo, tudi številko zemljiškoknjižnega vložka, številko enote vložka, leto vpisa, površino lastniške enote, status lastniške enote (podobno kot pri zgradbi) ter celo kratek opis lastniške enote (tako zasnovan Register zgradb omogoča povezavo na zemljiško knjigo $\mathrm{E}$ ter njene tabele lastnikov, uporabnikov in bremen). Kot smo že povedali, pa današnja zemljiška knjiga ne omogoča sprotnega spreminjanja sprememb zem,ljišča. Zato smo zgradili razširjeno podatkovno bazo registra zgradb, $v$ kateri so poleg že prej omenjenih tabel JEDR in EAl še tabeli lastnikov in uporabnikov. Preko njih lahko torej sproti spremljamo spremebe lastništva, ko prodajalec in kupec registrirata prenos lastništva na zato pristojnem občinskem organu. Čeprav ti podatki še niso lastniško-pravno veljavni, vendar nudijo nezakasnjeno spremljanje sprememb lastništva. Podobno spremljamo tudi spremembe uporabnikov (spremebe pravic rabe). S pomočjo omenjenih podatkov zadovoljujemo tudi prostorsko-planerski vidik, oziroma spremljanje alokacije dejavnosti v prostor, saj so lastniki oziroma uporabniki, ki so pravne osebe, prav tako registrirani $v$ tabelah. $V$ ta namen si pomagamo tudi $z$ Enotnim registrom obratovalnic in skupnosti (EROS).

Poleg sprememb lastništva pa $\mathrm{v}$ razširjeni podatkovni bazi registra zgradb lahko spremljamo tudi vse druge dogodke na zgradbi. Mišljeno je tako spremljanje gradnje in vzdrževanja kot tudi vseh vrst transakcij. Le-te lahko spremljamo $\mathrm{v}$ tabeli dogodkov. Zgrajeni sta, tako tabela dogodkov na zgradbi, kot tudi tabela dogodkov na enoti v njej. Poleg sprotnega spremljanja vrednosti dogodka po navedbi, pa lahko zgradbe tudi ocenjujemo. Tabele transakcij dajejo namreč direkten vpogled v gibanje cen nepremič- 
nin kot odraz maksimalne uporabne vrednosti nepremičnine za potencialne uporabnike nepremičnin. Te je smiselno spremljati tako preko prenosa pravic rabe $z$ deklarirano rento kot ob prenosu lastništva, kjer je podana cena kot kapitalizacija rente. $\mathrm{V}$ ta namen si pomagamo s podatki iz tabel tehničnih lastnosti zgradbe, enote ali celo prostora. Na spodnji sliki 8 so označene povezave med osnovnima tabelama Registra zgradb ter ostalimi tabelami, ki skupaj tvorijo razširjeno podatkovno bazo registra zgradb.

Slika 8: Razširjena podatkouna baza registra zgradb.

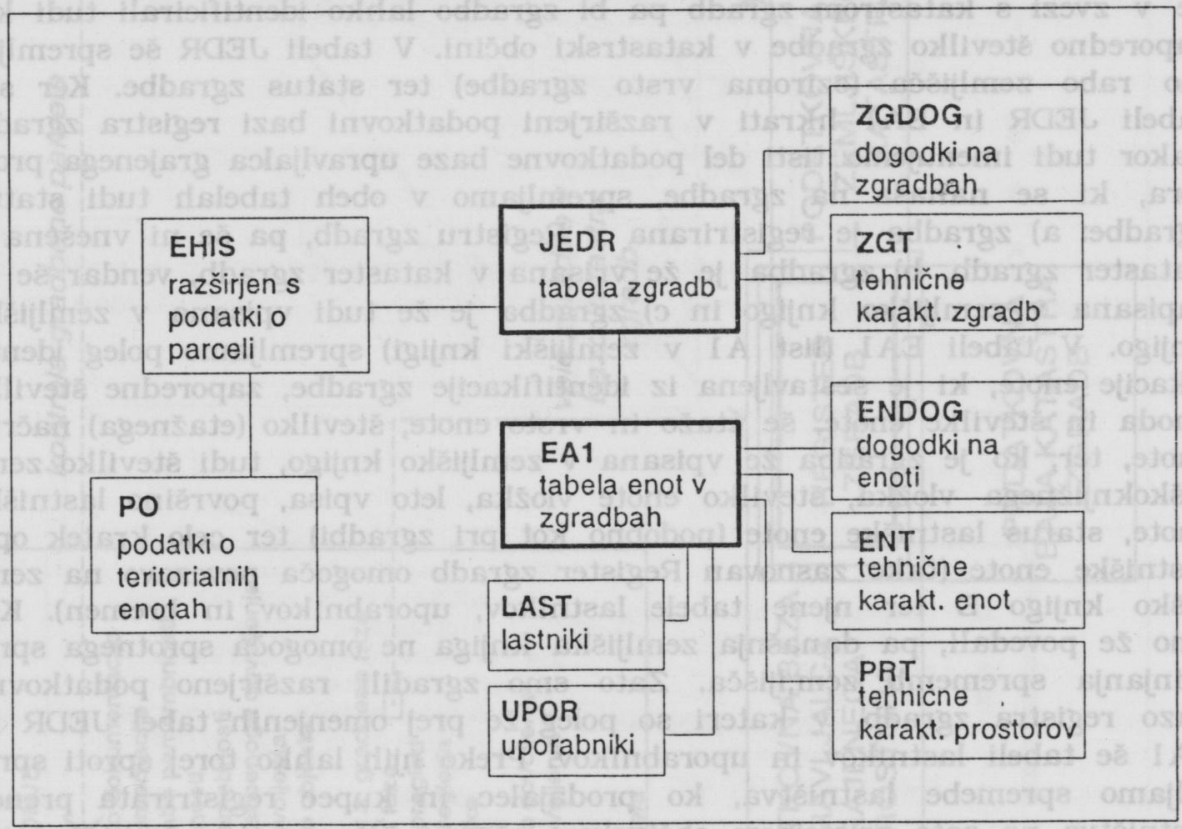

V tako zasnovani razširjeni podatkovni bazi registra zgradb dobimo preko tabele dogodkov na zgradbah podatek o vrednosti vloženega kapitala v zemljišče in podatek o menjalni vrednosti nepremičnine, kot odraz posameznih dogodkov na zgradbah in odločitev upravljalcev prostora, ki se nanašajo tako na lokacijo samo kot tudi na druge lokacije v okolici.

\section{UGOTAVLJANJE VREDNOSTI NEPREMIČNIN NA TEMELJU REGISTRA ZGRADB - SISTEM SLOCAMA}

Že študija posledic odločitev v monocentričnih urbanih sistemih je pokazala, da se te posledice kažejo kot sprememba menjalne vrednosti nepremičnine kot maksimum uporabnih vrednosti posameznih potencialnih uporabnikov nepremičnin. Ugotavljamo lahko tudi v obratni smeri, da je mogoče 
preko spremljanja cen nepremičnin na trgu oceniti vpliv posameznih odločitev na uspešnost razvoja naselij. Takšna analiza nam omogoča ovrednotenje minulih odločitev in nudi podporo za nadaljnja odločanja o posegih in omejitvah $\mathrm{v}$ prostoru.

Vrednotenje nepremičnin izvajajo v svetu na več načinov. Med najpogostejšimi so:

vrednotenje preko tržnih vrednosti nepremičnin,

vrednotenje uporabne vrednosti nepremičnine,

vrednotenje preko analize investiranja $\mathrm{v}$ nepremičnine.

Ponavadi se srečamo s kombiniranim načinom vrednotenja.

V Sloveniji je dolga leta prevladoval tretji način vrednotenja $z$ manjšimi modifikacijami glede na lego in izpostavljenost negativnim vplivom (vlažnost, motenost zaradi prehoda, senčni prostor, hrup..). Vrednost nepremičnine se je pogosto smatrala kar enaka vrednosti vloženega kapitala $v$ nepremičnino, zmanjšana zaradi dotrajanosti objektov. $\mathrm{V}$ zadnjem času se je izpostavljal vpliv lege kot pomembnejši faktor - upravljalci prostora so ga uvedli v sistem določanja višine nadomestil za uporabo stavbnih zemljišč, s čimer so želeli zajeti rento od rabe mestnih zemljišč - vendar je bil ta sistem zajemanja izredno grob in znotraj con neselektiven.

Pri nas je na problem vrednotenja nepremičnin glede na njihovo tržno vrednost opozoril že prof. Tone Klemenčič $v$ svojih študijah o zemljiški renti in ceni zemljišča kot njegovi kapitalizaciji. Tako je ta avtor $v$ delu "Mestna renta in cena stavbnega zemljišča", IKG FAGG, 1979. leta tudi prvič predlagal vsebino podatkovne zbirke o transakcijah $z$ nepremičninami, ki naj bi $z$ nekaterimi dopolnili danes postala del podatkovne baze upravljalcev nepremičnin $\mathrm{v}$ naši družbi $\mathrm{v}$ sistemu SLOCAMA (CAMA angl 'computer assisted mass appraisal').

Faktorji, ki vplivajo na vrednost nepremičnin so bili podrobneje obravnavani v publikaciji M. Bogataj: Ugotavljanje in zajemanje rentnih diferencialov' (1985). Iz omenjenega dela je razvidno, da ni smiselno ločeno obravnavati kmetijskih zemljišč od stavbnih zemljišč. Pokazalo se je tudi, da je mogoče $z$ ustrezno davčno oziroma rentno politiko regulirati razvoj naselij z manjšimi planerskimi prisilami, upoštevajoč tržne mehanizme $v$ prostorskem oligopolu. $\mathrm{V}$ tem delu je bil dan poudarek na ceni stavbnega zemljišča, na katerem ni zgrajenega objekta. Poleg tehničnih in lokacijskih lastnosti, ki temeljijo na evklidski razdalji med objekti, je bil velik poudarek na vrsti rabe, $\mathrm{ki}$ je tudi $\mathrm{v}$ našem sistemu pomemben kazalec. $\mathrm{V}$ novejših raziskavah smo evklidsko razdaljo nadomestili s splošno funkcijo razdalje, $\mathrm{d}(\mathbf{a}, \mathbf{b})$.

$\mathrm{V}$ procesu lastninjenja, ‘ ki nas čaka, ni dovolj analiza tržne vrednosti nepremičnin niti ne samo analiza vrednosti investicij $v$ zgrajene objekte $v$ 
prostoru, ampak posamezne lastnosti nepremičnin, ki so vsebovane v različnih tabelah predlagane podatkovne baze. Vrednost nepremičnine lahko ocenjujemo kot linearno kombinacijo dveh Coob-Douglosovih funkcij: Coob-Douglasove lokacijske funkcije, in Coob-Douglasove funkcije vrednosti golega objekta, ki lahko $\mathrm{v}$ nekaterih primerih celo negativno vpliva na vrednost nepremičnine - in to takrat, ko bi za optimalno rabo morali prvotni objekt celo rušiti in zgraditi nov objekt. Ustreznost izbire Coob-Douglasove funkcije lahko preverimo s hipotetičnimi transformacijami, ki jih omogočajo parametri hedoničnega indeksa. Vrednost nepremičnine je odvisna tudi od stopnje zajemanja učinkov družbenih vlaganj preko dav-

Slika 9: Sistem SLOCAMA in njegova vpetost $v$ podatkoune strukture GIS-a.

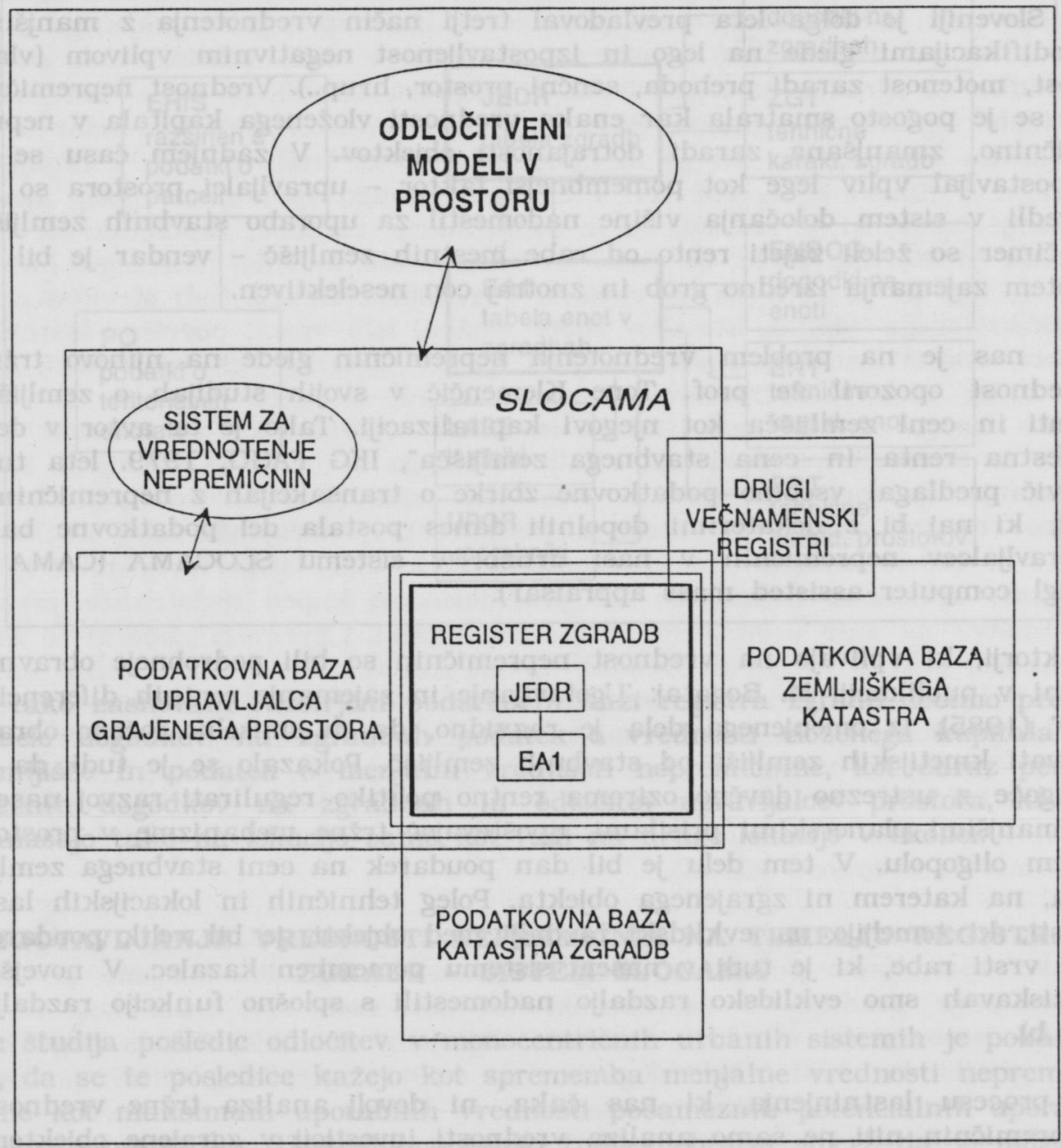


kov ali nadomestil za rabo zemljišč $\mathrm{v}$ procesu rabe nepremičnine. Zato je možno postaviti zanesljivejšo ceno pri prenosu lastništva šele pri poznani politiki zajemanja rentnih diferencialov, ki so odraz minulih vlaganj $v$ naselje. Končni sistem SLOCAMA, katerega vpetost $\mathrm{v}$ podatkovne strukture GIS-a je razvidna iz slike 9 , naj bi tako omogočal tudi analizo vpliva zemljiške in predvsem davčne politike na vrednost nepremičnin.

Opomba: Ogled v prispevku omenjene aplikacije razširjene podatkovne baze registra zgradb in njenega povezovanja $s$ katastrom zgradb je možen na FAGG, Jamova 2, v sobi 110.

\section{LITERATURA IN VIRI}

Alonso, W., 1964: Location and Land Use - Toward a General Theory of Land Rent. Harvard University, Cambridge.

Alonso, W., 1971: The economics of urban size, Papers and Proceedings of the Regional Science Association, 26.

Bogataj, M., 1985: Ugotavljanje in zajemanje rentnih diferencialov, IKG, FAGG, Ljubljana.

Bogataj, M., Bogataj, L., 1986: Two level dynamic programming of the spatial distribution of communal equipment and land use, Second meeting of EURO working group "Location Theory", Herceg Novi.

Bogataj, M., Bogataj, L., 1986: Multilevel management of water supply systems as a special case of dynamic inventory problems, Inventory in Theory and Practice (ed. A. Chikan), Studies in Production and Engineering Economics, vol. 6, Elsevier Scientific Publishing Co., Amsterdam - New York, 443-450.

Bogataj, M., Bogataj, L., 1988: Computer Assisted Control of Urban Growth Through the Valuation of the Communal Equipment and the Land Use Value, CAMA III, Harvard Law School and Lincoln Institut of Land Policy, Cambridge, Massachusets.

Bogataj, M., Drobne, S., 1990: Vloga geodezije pri reševanju ekoloških problemov, Geodetski vestnik, Ljubljana, 34(1):41-49.

Bogataj, M., Drobne, S., 1991: Reševanje demografsko in polucijsko ogroženih področij $v$ hierarhiji naselij Slovenije, IB revija, Ljubljana, $\mathrm{XXV}(1-2): 22-33$.

Bogataj, M., Drobne, S., Ferlan, M., 1991: Register zgradb v jedru GIS, referat na 24. Geodetskem dnevu, Geodetski vestnik, Ljubljana, 34(3):123-131.

Bogataj, M., Bogataj, L., 1992: Combinatorial optimatization of the location - inventory problem, Int.J. of Prod. Econ., Elsevier, (26): 273 - 276.

Chinitz, B., 1990: Growth management - Good for the town, bad for the nation?, Journal of the American Planning Association, 56(1).

Cumberland, J.H., 1990: Public choice and the improvement of policy instruments for environmental management, Ecological Economics, 2(2).

Evans, A., 1985: Urban Economics, Blackwell.

Fisch O., 1980: The accuracy of changes of urban land values as a me- 
asure of social benefits from public programs, Regional Science and Urban Economics, (10): 473-489.

Hafkamp, W., Nijkamp, P., 1981: Multiobjective modelling for economic-environmental policies, Environment and Planning A, 13 (1).

Klemenčič, T., 1979: Mestna renta in cena stavbnega zemljišča, IKG, FAGG, Ljubljana.

Maier-Rigaud, G., 1991: On Divergences between Internalisation and Environmental Policy, revised version of a presentation given at the International Conference on Human Ecology at Goteborg, Sweden. 